\title{
Analysis of the relationship between the indices of United Nations Development Program and Gini coefficient and health indicators
}

\author{
Birleşmiş Milletler Kalkınma Programı Endeksleri ve Gini katsayısı \\ ile sağlık göstergeleri arasındaki ilişkinin incelenmesi
}

iD Gülcan Şantaş

Dr. Öğr. Üyesi, Yozgat Bozok Üniversitesi İktisadi ve İdari Bilimler Fakültesi Sağlık Yönetimi Bölümü, Yozgat, Türkiye.

Received: 02.09.2020, Accepted: 17.02.2021

\begin{abstract}
Objective: This study aimed to investigate the relationship between the United Nations Development Program (UNDP) indices used to measure development, inequality, and poverty; the Gini coefficient which is used to measure equality in income distribution; and a variety of health variables. Methods: The health indicators consisted of 19 variables grouped under the titles of: life expectancy, mortality, morbidity, healthcare utilization, health infrastructure and health system. The study covered the 194 member countries of the World Health Organization (WHO). However, since some countries did not have UNDP Indices and Gini coefficient data, the analyses were carried out on countries with complete datasets. For this study, the UNDP indices and Gini coefficient data were obtained from the "2018 Human Development Report" published by the UNDP. Data on health variables were obtained from the "Global Health Observatory (GHO) Data", which is a WHO database. Correlation analyses was performed in the study. Results: The analyses of the study show that there is a statistically significant moderate, high, and very high correlation between health variables, UNDP indices and the Gini coefficient. This study indicates that high development is associated with higher health, and high poverty and inequality are associated with high mortality and disease. Conclusion: The findings of this study demonstrate a positive correlation between economic development, income equality and positive health indicators. These findings are consistent with similar findings in the literature.
\end{abstract}

Keywords: Development, United Nations Development Program Indices, WHO countries

Correspondence: Gülcan Şantaş, Yozgat Bozok Üniversitesi İktisadi ve İdari Bilimler Fakültesi Sağlık Yönetimi Bölümü, Atatürk Yolu 7. Km. Merkez/Yozgat, Türkiye. E-mail: gulcan.santas@bozok.edu.tr. Tel: 0 (354) 2421040. Cite This Article: Şantaş G. Birleşmiş Milletler Kalkınma Programı Endeksleri ve Gini katsayısı ile sağlık göstergeleri arasındaki ilişkinin incelenmesi. Turk J Public Health 2021;19(1):1-19

(C) Copyright 2021 by the Association of Public Health Specialist (https://hasuder.org.tr)

Turkish Journal of Public Health published by Cetus Publishing. 


\section{ÖZ}

Amaç: $\mathrm{Bu}$ çalışma, Birleşmiş Milletler Kalkınma Programı (UNDP) tarafından geliştirilen gelişmişlik, eşitsizlik ve yoksulluk gibi olguları ölçmeye yarayan endeksler ve gelir dağılımında eşitliği ölçmeye yarayan Gini katsayısı ile sağlık değişkenleri arasında ilișki olup olmadığının belirlenmesi amacıyla gerçekleștirilmiştir. Yöntem: Sağlık değişkenleri yaşam beklentisi, mortalite, morbidite, sağlık hizmeti kullanımı ve sağlık altyapısı ve sağlık sistemi başlıklarıyla gruplanmış 19 değişkenden oluşmaktadır. Araştırma, Dünya Sağlık Örgütü üyesi 194 ülkeyi kapsamaktadır. Ancak ülkelerin tamamında UNDP Endeksleri ve Gini katsayısı verileri olmadığı için analizler verileri tam olan ülkeler üzerinden gerçekleştirilmiştir. Çalışmada UNDP Endeksleri ve Gini katsayısı verileri UNDP tarafından yayınlanan "2018 İnsani Gelişmişlik Raporu"ndan, sağlık değişkenlerine ilişkin verilere ise Dünya Sağlık Örgütü veri tabanı olan "Global Health Observatory (GHO) Data" veri setinden ulaşılmıştır. Araştırmada korelasyon analizi uygulanmıştır. Bulgular: Araştırmanın analizleri sağlık değişkenleri ile Endeksler ve Gini katsayısı arasında istatistiksel olarak anlamlı şekilde orta, yüksek ve çok yüksek korelasyon olduğunu göstermektedir. Çalışma yüksek gelişmişliğin yüksek sağlı; yüksek yoksulluk ve eşitsizliğin ise yüksek ölüm oranı ve hastalık ile ilişkili olduğu bulgusuna işaret etmektedir. Sonuç: Çalışma sonucunda daha fazla gelişmişliğin diğer faydalarının yanında daha iyi sağlık ya da tersi olarak daha iyi sağlığın daha fazla gelişmişlik anlamına geldiği söylenebilir.

Anahtar kelimeler: Gelişmişlik, Birleşmiş Milletler Kalkınma Programı Endeksleri, DSÖ ülkeleri

\section{Giriş}

Uzun yıllar gelişmiş ülkeler ekonomik büyümeyi sağlamış ülke olarak kabul edilmiş ve ülkeler Gayri Safi Milli Hâsıla (GSMH) ya da Gayri Safi Yurtiçi Hâsıla (GSYH) seviyelerine göre sıralanmıştır. Ancak ülkelerin gelişmişliğini belirlemede ekonomik büyümenin ya da ekonomik durumun yeterli olmadığının anlaşılması üzerine alternatif ölçüt ihtiyacı ortaya çıkmıştır.

Gelişmişlik, ekonomik büyüme yanında kalkınma kavramiyla ifade edilmeye başlanmıştır. Kalkınma ekonomik büyüme yanında ekonomik, sosyal, kültürel ve diğer yapıların da değiștirilmesi ve yenileștirilmesi sürecidir. ${ }^{1,2}$ Ancak kalkınma ve gelişmenin ölçümü zordur ve tek ve standart bir ölçüsü yoktur. ${ }^{3} \mathrm{Bu}$ ihtiyaçları gidermeye yönelik UNDP tarafından 1990 yılından itibaren İnsani Gelişme Raporu yayınlanmakta ve süreç içerisinde gittikçe artan endeksler oluşturulmaktadır. Gelişmişliği ölçmeye yönelik İnsani Gelişmişlik Endeksi (İGE), Eşitsizliğe Uyarlanmış İnsani Gelişmişlik Endeksi (EUIGE), Çok Boyutlu Yoksulluk Endeksi (ÇBYI), Cinsiyet Eşitsizliği Endeksi (CEE) ve Cinsiyet Gelişmişlik Endeksi (CGE) kullanılmaktadır.

$\mathrm{Bu}$ çalışmada UNDP Endeksleri kavramsal olarak açıklanmakta, Endeksler ve Gini katsayısı ile sağlı göstergeleri arasında ilişki olup olmadığı incelenmektedir. Böylece sağlık göstergeleri ile gelişme ya da kalkınma, eşitsizlik, gelir dağılımında eşitsizlik ile ilişkisi değerlendirilebilecektir. Alanyazında bu kapsamda çalışmaya rastlanılmadığından bu çalışmanın ilgili alanyazına katkı sağlayacağı düşünülmektedir. 


\section{Kavramsal çerçeve}

UNDP tarafından insani gelişmişliğin ölçümünde bileşik endeks (composite index) şeklinde oluşturulmuş beș endeks bulunmaktadır. $\mathrm{Bu}$ endeksler ve endekslerin temel özellikleri şu şekildedir:

\section{1. İnsani Gelişmişlik Endeksi (Human Development Index):}

İGE, gelișmișliğin değerlendirilmesinde yalnızca ekonomik büyümenin yetersiz olduğunu ve insanların kapasite ve yeteneklerinin nihai değerlendirmede esas alınması gerektiğini vurgular. İGE, ulusal politika tercihlerinin sorgulanmasını da sağlamaktadır. Örneğin, aynı kişi başına düşen GSMH miktarına sahip olan iki ülkenin farklı İGE değerinde olması, politika tercihleri ve önceliklerin belirlenmesinin sorgulanmasına neden olabilmektedir. IGE, insani gelişmişliğin ölçümünü kolaylaştırmaktadır ve insani gelişmişlik için odaklanılması gereken boyut ve göstergeleri ortaya koymaktadır. Ancak İGE; eşitsizlik, yoksulluk, insan güvenliği, güçlendirme vb. gibi konularda bilgi sağlamamaktadır. $\mathrm{Bu}$ konulara ilişkin izleyen kısımda ele alınacak bileșik endeksler geliştirilmiștir. ${ }^{4}$

İGE, insani gelişmişliğin üç boyutunun bir özetidir. Bu üç boyut: Uzun ve sağlıklı yaşam, bilgi ve saygin bir yaşam standardı. İGE, bu üç boyutun geometrik ortalamasıdır. İGE'nin hesaplanmasında iki aşama bulunmaktadır: İlk aşamada boyutların endeksleri oluşturulmakta, ikinci aşamada ise oluşturulan endekslerin geometrik ortalamaları toplanarak İGE'ye ulaşılmaktadır.

Uzun ve sağlıklı yaşam boyutu, doğumda yaşam beklentisi göstergesi ile ölçülmektedir. Doğumda yaşam beklentisi minimum 20, maksimum 85 yll olarak hesaplamaya dâhil edilmektedir. Bilgi boyutu, beklenen okullaşma yılı ve ortalama okullaşma yılı ile hesaplanmaktadır. Hesaplamalarda beklenen okullaşma yılı minimum 0 , maksimum 18, ortalama okullaşma yılı ise sırasıyla 0 ve 15 olarak alınmaktadır. Saygın bir yaşam, kişi başı GSMH değişkeni ile ölçülmektedir ve bu göstergenin alabileceği minimum değer $100 \$$, maksimum değer ise 75.000 \$'dır. Her bir boyut için minimum ve maksimum değerler belirlendikten sonra hesaplama şu formül yardımıyla yapılmaktadır:

Boyut Endeksi $=\frac{\text { Gerçek değer }- \text { Minimum deg̃er }}{\text { Maksimum değer }- \text { Minimum değer }}$

Formül yardımıyla üç boyut endeksi hesaplandiktan sonra geometrik ortalamaları hesaplanmakta ve hesaplanan üç ortalama toplanarak ülkelerin İGE değerleri oluşturulmaktadır. İGE değeri 0 ile 1 arasında değer almakta ve değerin 1'e yaklaşması gelişmişliğin arttığını göstermektedir. Endeks değerlerine göre dört kategori oluşturulmuştur: 0,000-0,549 arası düşük, 0,550-0,699 orta, 0,700-0,799 yüksek ve $0,800-1,000$ en yüksek insani gelişmişliği göstermektedir. İGE 2019 raporunda 189 ülke için endeks değerinin hesaplandığı ve 62 ülkenin çok yüksek, 54 ülkenin yüksek, 37 ülkenin orta, 36 ülkenin ise düşük insani gelişmişlik kategorisinde olduğu ifade edilmektedir. ${ }^{5}$

Şekil 1'de İGE'nin boyutları, göstergeleri ve boyut endeksleri verilmektedir. Görüldüğü gibi İGE; sağlık, eğitim ve ekonomi gibi gelişmişliğin çok önemli üç boyutunu kapsamaktadır.

Tablo 1'de bazı ülkelerin İGE değerleri ve İGE bileșenleri verilmektedir. Tablo incelendiğinde ilk sırada Norveç'in yer aldığı görülmektedir. Türkiye $0.806^{\prime} l ı k$ değeriyle çok yüksek insan gelişmişlik kategorisinde yer almakla birlikte 59. sıradadır. Hesaplamaya alınan 189 ülke içerisinde son sırada Nijer yer almaktadır.

2. Eşitsizliğe Uyarlanmış İnsani Gelişmişlik Endeksi (The InequalityAdjusted Human Development Index):

Eşitsizliğe Uyarlanmıș İnsani Gelișmișlik Endeksi (EUIGE), İGE'nin boyutlarında görülen eşitsizlikleri dikkate alarak İGE'yi hesaplamaktadır. Boyutlar, ülke vatandaşı arasında eşit dağılmadığı için EUİGE değerleri İGE değerlerinden düşük çıkmaktadır. Ülkede mükemmel bir eşitlik olması durumunda İGE ile EUİGE birbirine eşit olmaktadır (UNDP, 2019a). Şekil 2'de EUİGE'nin grafiksel gösterimi verilmektedir. Şekil incelendiğinde boyutlar 
İGE ile aynı olmakla birlikte EUİGE'de boyutların hesaplanmasında değerlerden eşitsizliğin miktarı kadar indirim yapılmaktadır. 2018 İGE raporuna bakıldığında EUIGE'nin $\% 5$ ile $\% 40$

BOYUTLAR Uzun ve Sağlıklı Yașam

GÖSTERGELER Doğumda Yaşam

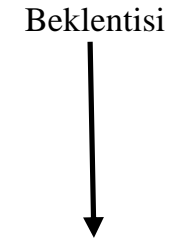

BOYUT ENDEKSİ Yaşam Beklentisi Endeksi

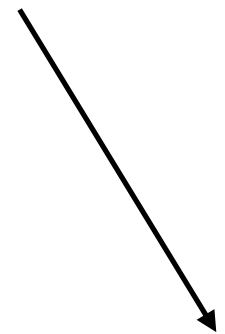

INNSANI GELIŞMIŞLIIK ENDEKSİ (İGE) arasında değișen oranlarda İGE'den daha az olduğu görülmektedir.5,6

$\underline{\text { Bilgi }}$

Saygin Bir Yassam Standardı

Beklenen Okullaşma Yı11

Kişi Başı GSMH (SGP \$)*

Ortalama Okullaşma Y11

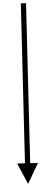

Eğitim Endeksi

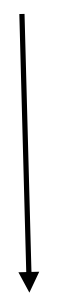

GSMH Endeksi

Şekil 1. İnsani Gelişmişlik Endeksinin Grafiksel Gösterimi

* Satın Alma Gücü Paritesi (SGP)

Kaynak: (UNDP, 2019b) ${ }^{6}$

Tablo 1. Ülkelerin İGE Değerleri ve İGE bileșenleri

\begin{tabular}{|c|c|c|c|c|c|}
\hline Ülke & İGE Değeri & $\begin{array}{l}\text { Doğumda } \\
\text { Yaşam } \\
\text { Beklentisi }\end{array}$ & $\begin{array}{l}\text { Beklenen } \\
\text { Okullaşma } \\
\text { Yılı }\end{array}$ & $\begin{array}{l}\text { Okullaşma } \\
\text { Yılı } \\
\text { Ortalaması }\end{array}$ & $\begin{array}{l}\text { Kişi Başı } \\
\text { GSMH }(2011 \\
\text { Yllı SGP, \$) }\end{array}$ \\
\hline 1. Norveç & 0.954 & 82.3 & 18.1 & 12.6 & 68.059 \\
\hline 2. İsviçre & 0.946 & 83.6 & 16.2 & 13.4 & 59.375 \\
\hline 59. Türkiye & 0.806 & 77.4 & 16.4 & 7.7 & 24.905 \\
\hline 116. Misır & 0.700 & 71.8 & 13.1 & 7.3 & 10.744 \\
\hline 152. Pakistan & 0.560 & 67.1 & 8.5 & 5.2 & 5.190 \\
\hline 189. Nijer & 0.377 & 62.0 & 6.5 & 2.0 & 912 \\
\hline
\end{tabular}

Kaynak: UNDP, $2019 \mathrm{a}^{5}$ 


\section{3. Çok Boyutlu Yoksulluk Endeksi (The Multidimensional Poverty Index):}

Yoksulluk, genel olarak gelir yokluğu şeklinde anlaşılmakla birlikte farklı yoksunlukları kapsayan bir kavramdır. Alanyazında yoksulluğun çeşitli şekillerde tanımlandığı görülmektedir. Genel olarak yoksulluk, nesnel olarak belirlenmiş düzeyinde altında olmak şeklinde tanımlanmaktadır. ${ }^{7} \quad$ Yoksulluğun tanımındaki çeşitlilik ve farklılık yoksulluğun çok sayıda türünün bulunmasından kaynaklanmaktadır. Mutlak yoksulluk, göreli yoksulluk, insani yoksulluk öne çlkan yoksulluk türleri arasındadır. Yoksulluğun hemen her ülkede görülmesi, başta uluslararası dokümanlar olmak üzere çeşitli ortamlarda ortadan kaldırılması gereken bir olgu olarak görülmesine koşut olarak yoksulluk ölçülmeye çalışılmakta, diğer bir ifadeyle yoksulluğun yoğunluğu ortaya koyulmaya çalışılmaktadır. Yoksulluk ölçütleri olarak adlandırılabilen araçlar; kişi sayısı endeksi,

BOYUTLAR Uzun ve Sağlıklı Yasam

GÖSTERGELER

Doğumda Yaşam

Beklentisi

BOYUT ENDEKSI

Yaşam Beklentisi

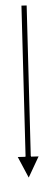

EŞİTSIZLLIĞE

Eşitsizliğe Uyarlanmış

UYARLANMIŞ

Yaşam Beklentisi Endeksi

ENDEKS

Sen endeksi, refah endeksi ve UNDP tarafından kullanılan çok boyutlu yoksulluk endeksidir. $.5,8,9$

Çok boyutlu yoksulluk endeksi (ÇBYE), yoksulluğun gelir yanında çok boyutu olan bir olgu olduğunu vurgulamaktadır ve Şekil 3'te görüldüğü gibi sağlık, eğitim ve yaşam standardından oluşan üç boyutu ve 10 göstergesi bulunmaktadır. ÇBYE'nin hesaplanmasinda araștırmalarından gelen veriler kullanılmaktadır. Ayrica endeksin hesaplanabilmesi için tüm göstergelere ilişkin verinin aynı veri setinden olması gerekmektedir. Araştırmadaki her birimin (birey ya da hane) üç boyut ve 10 göstergeye göre endeks değeri hesaplanmakta ve endeks en fazla \%100 olabilmektedir. Üç boyut olduğu için her bir boyutun ağırlığı 1/3'tür. Boyutlar yardımıyla yoksulluğun yoğunluğu ve kiși sayısı oranı ölçütlerine ulaşılmakta ve bu iki ölçüt ile de ÇBYE hesaplanmaktadır.

Bilgi

Beklenen Okullaşma Yılı

Ortalama Okullaşma Y1lı

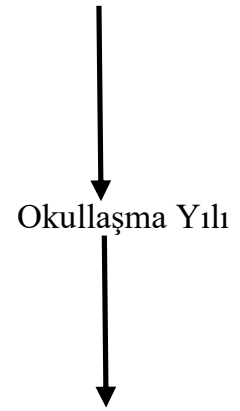

Eşitsizliğe Uyarlanmış

Eğitim Endeksi

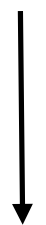

\section{$\underline{\text { Saygın Bir Yașam Standardı }}$}

Kişi Başı GSMH (SGP \$)
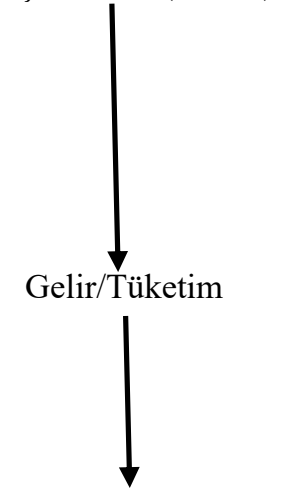

Eşitsizliğe Uyarlanmış

Gelir Endeksi

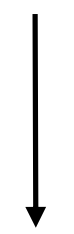

\section{EŞITSSIZLİĞE UYARLANMIŞ İNSANI GELIŞMIŞLİK ENDEKSİ (EUİGE)}

Şekil 2. Eșitsizliğe Uyarlanmış İnsani Gelişmişlik Endeksinin Grafiksel Gösterimi

Kaynak: UNDP, $2019 \mathrm{~b}^{6}$ 


\section{Cinsiyet Eşitsizliği Endeksi (Gender Inequality Index)}

Cinsiyet eşitsizliği, gelişmiş ve gelişmekte olan tüm toplumlarda görülebilen bir olgudur. Özellikle kadınlar toplumsal norm ve değer yargılarına göre sağlık, eğitim, iş hayatı gibi alanlarda ayrımcllıkla karşılaşabilmektedir. Türkiye'de olduğu gibi ülkelerin mevzuatlarında kadınlara pozitif ayrımcılık yapılabileceği ve bu durumun adaletsizlik ya da haksızlık olarak nitelenemeyeceği şeklinde hükümler bulunabilmektedir.

Cinsiyet Eşitsizliği Endeksi (CEE), Şekil 4'te görüldügü gibi üreme sağlığl, güçlendirme ve iş (emek) pazarı gibi üç boyutta cinsiyet temelli eşitsizliği göstermektedir. CEE, cinsiyet eşitsizliği nedeniyle İGE'deki potansiyel kaybı ifade etmektedir. Endeks değeri, 0 ile 1 arasında değişmekte ve 1'e yaklaştıkça eşitsizliğin arttığını göstermektedir. ${ }^{6}$

\section{Cinsiyet Gelişmişlik Endeksi (Gender Development Index):}

Cinsiyet Gelişmişlik Endeksi (CGE), cinsiyet eşitsizliği gibi cinsiyetler arasındaki eşitsizliğe odaklanmaktadır. Şekil 5'te görüldüğü gibi CGE, İGE gibi hesaplanmaktadır. Yaşam beklentisi, eğitim ve GSMH endekslerinden oluşan İGE kadın ve erkekler için ayrı ayrı hesaplanmaktadır. Daha sonra kadınlar için hesaplanan İGE, erkekler için hesaplanan İGE'ye bölünerek CGE bulunmaktadır. 6
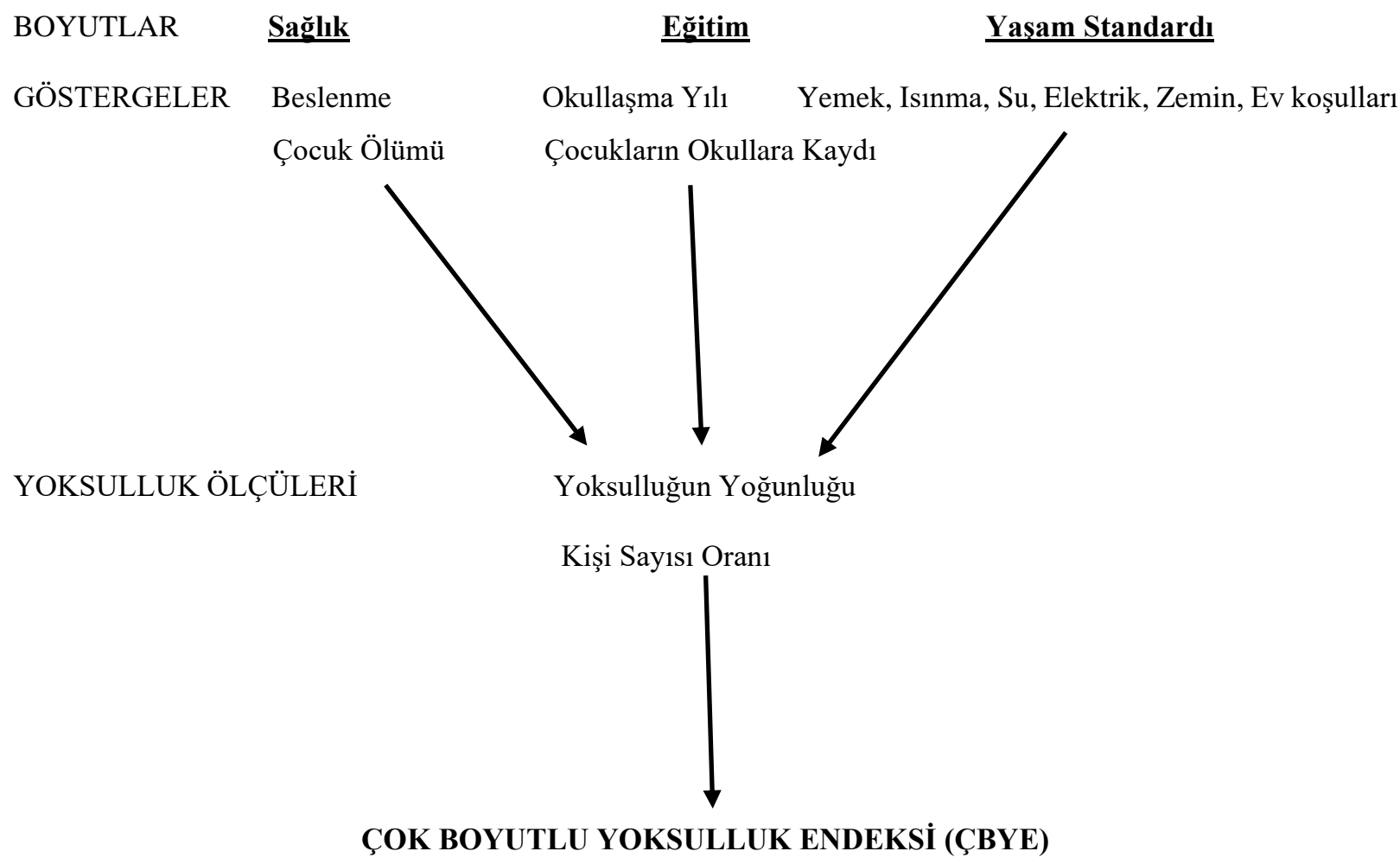

Şekil 3. Çok Boyutlu Yoksulluk Endeksinin Grafiksel Gösterimi

Kaynak: (UNDP, 2019b) ${ }^{6}$

\section{Gini Katsayısı:}

Gelir dağılımı, bir ülkenin gelişmişliğinin diğer bir ifadeyle kalkınmışlığının göstergeleri arasındadır. Gelir dağılımı; milli gelirin birey, bölge, toplumsal grup ya da üretim faktörleri arasında dağılımı şeklinde tanımlanmaktadır. ${ }^{10}$ Bir ülkenin ekonomik büyümesi önemli olmakla birlikte bu ekonomik zenginliğin bireyler arasında dağılımı da oldukça önemlidir. Gelirin bireyler arasında dağılımı eşit 
olmamakta diğer bir ifadeyle ülke geliri eşitsiz dağılabilmektedir. Gelir dağılımında eşitliğin ölçümünde çeşitli araçlardan yararlanılmaktadır.11 Gini katsayısı en fazla bilinen ve kullanılan ölçütlerdendir. Katsayı, 0 ile 1 arasında değişen değerler almakta, 0 tam eşitliği, 1 ise tam eşitsizliği göstermektedir. Gini katsayısının artışı diğer bir ifadeyle gelir dağılımında eşitliğin bozulması başta eğitim ve sağlık olmak üzere sosyo-ekonomik tüm alanlarda bozucu etki oluşturabilmektedir.

Tablo 2'de UNDP endeksleri ve Gini katsayısı açısından birinci, sonuncu durumdaki ülkeler ve Türkiye'nin mevcut durumu verilmektedir. Tablo incelendiğinde Türkiye'nin endeks değerlerinde daha iyi hale gelme ve gelir dağılımında eşitliği sağlama yönünde çaba harcaması gerektiği söylenebilir.
BOYUTLAR

Sağlık

GÖSTERGELER Ana Ölüm Oranı
Güclendirme

Is Pazarı

En Az Ortaöğretim Mezunu Kadın/Erkek Erkek ve Kadın İş Gücü

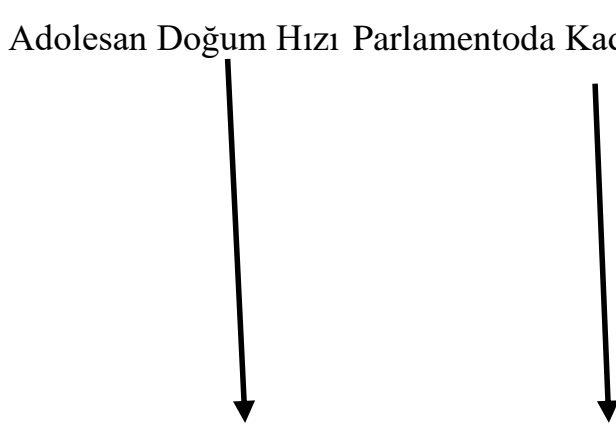

Kadın Üreme Sağlı̆ğ Endeksi

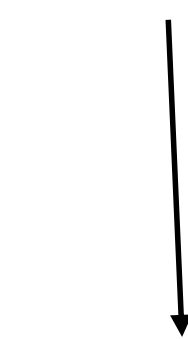

Kadın Cinsiyet Endeksi

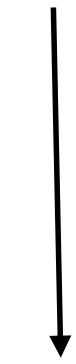

Kadın/Erkek

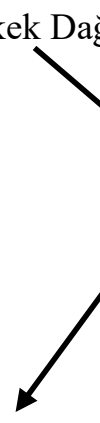

ek

Kadın/Erkek İş Gücü Endeksi

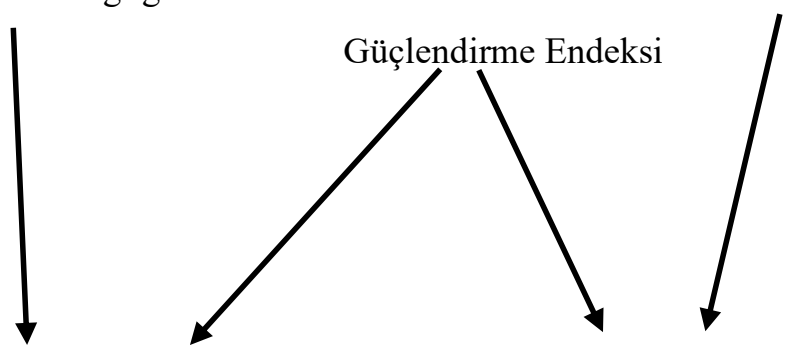

Erkek Cinsiyet Endeksi

\section{CİNSIYYET EŞiTSİZLİĞí ENDEKSİ (CEE)}

Şekil 4. Cinsiyet Eşitsizliği Endeksinin Grafiksel Gösterimi

Kaynak: (UNDP, 2019b) ${ }^{6}$ 


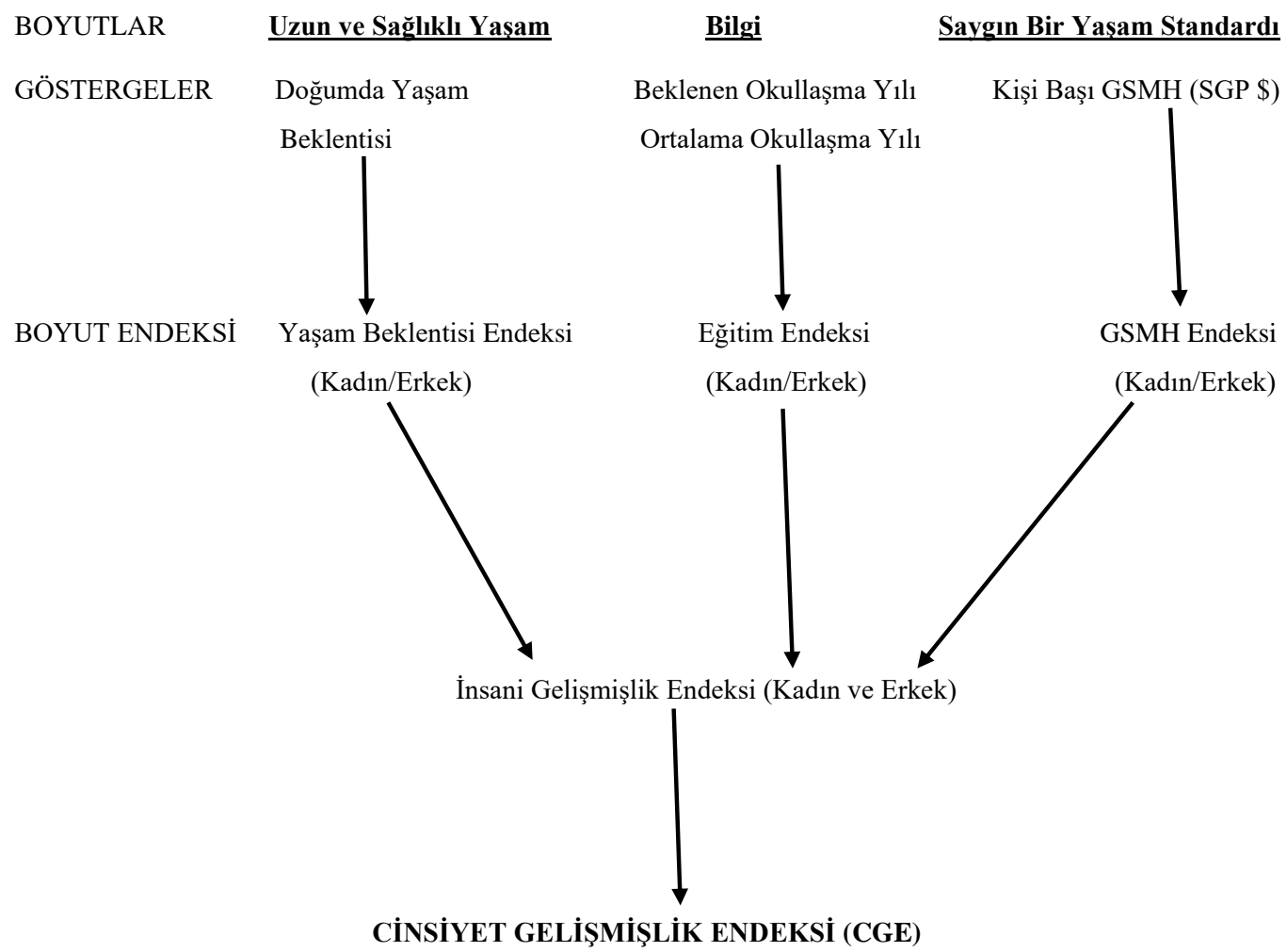

Şekil 5. Cinsiyet Gelişmişlik Endeksinin Grafiksel Gösterimi

Kaynak: (UNDP, 2019b) ${ }^{6}$

Tablo 2. En iyi, en olumsuz ülke ve Türkiye'nin endeks değerleri

\begin{tabular}{lllllll}
\hline Ülke & $\begin{array}{l}\text { İGE } \\
\text { Değeri }\end{array}$ & $\begin{array}{l}\text { EUIGE } \\
\text { Değeri }\end{array}$ & ÇBYE & CEE & CGE & $\begin{array}{l}\text { Gini } \\
\text { Katsayısı }\end{array}$ \\
\hline Birinci Sıra & 0.954 & 0.889 & 0.001 & 0.037 & 1.043 & 0.250 \\
Türkiye & 0.806 & 0.675 & - & 0.305 & 0.924 & 0.419 \\
Sonuncu Sira & 0.377 & 0.222 & 0.594 & 0.834 & 0.298 & 0.630 \\
\hline
\end{tabular}

Kaynak: (UNDP, 2019a) $)^{5}$

\section{Yöntem}

$\mathrm{Bu}$ çalışma, UNDP tarafından geliştirilen gelişmişlik, eşitsizlik ve yoksulluk gibi olguları ölçmeye yarayan endeksler ile sağlık değişkenleri arasında ilişski olup olmadığının belirlenmesi amaciyla gerçekleştirilmiştir. Çalışmada ayrıca gelir dağılımı ile sağlık değişkenleri ilişkisi de araştırılmış ve bu amaçla gelir dağılımı ölçütü olarak Gini katsayısı kullanılmıştır.
Çalışmanın diğer ana değişkeni durumundaki sağlık değişkenleri ise yaşam beklentisi, mortalite, morbidite, sağlık hizmeti kullanımı ve sağlık altyapısı ve sağlık sistemi başlıklarıyla gruplanmış, 19 değişkenden oluşmaktadır.

Çalışma, Dünya Sağlık Örgütü Üyesi 194 ülkeyi kapsamaktadır. Ancak ülkelerin tamamında UNDP Endeksleri ve Gini katsayısı verileri olmadığı için analizler verileri tam olan ülkeler üzerinden 
gerçekleştirilmiştir (bkz. Tablo 3). Çalışmada UNDP Endeksleri ve Gini katsayısı verileri UNDP tarafından yayınlanan 2018 İnsani Gelişmişlik Raporundan

(http://hdr.undp.org/sites/default/files/hd r2019.pdf) ${ }^{6}$ elde edilmiştir. Sağllk değişkenlerine ilişkin verilere ise Dünya Sağlık Örgütü veri tabanı olan "Global Health Observatory (GHO) Data" veri setinden

(https://www.who.int/gho/publications/w orld_health_statistics/2020/en/) ${ }^{12}$ ulaşılmıştır.

Çalışmada gelişmişlik ile sağlık arasındaki ilişkinin belirlenmesi amacı doğrultusunda korelasyon analizi yapılmıștır. Değişkenlerin tamamının normal dağılım göstermemesi nedeniyle korelasyon analizinde katsayılar Spearman Sira Korelasyon Katsayısı ile hesaplanmıştır. Analizler, Statistical Package For Social Sciences (SPSS), versiyon 21 ile yapılmıştır.
Çalışmada ilgili veri tabanlarının herkesin kullanımına açık olması, birincil veri toplama araçlarından yararlanılmaması nedeniyle etik kurul izni alınması gerekli görülmemiştir.

\section{Bulgular}

Tablo 3'te Endeksler ve Gini katsayısına ilişkin tanımlayıcı istatistikler verilmektedir. Endeks değerlerine bakıldığında İGE ortalamasının 0.709 ile yüksek, EUİGE ise 0.586'llk ortalama ile orta düzeyde olduğu görülmektedir. Sadece gelişmekte olan ülkeleri kapsaması nedeniyle 71 ülkeye ilişkin verilerin yer aldığ ÇBYE maksimum \%59.4, en fazla 1 olabilen CEE ise 0.834 ve CGE ortalaması ise 0.934'dür. Araştırma kapsamındaki 151 ülkenin Gini katsayısına ilişkin verilerine bakıldığında en az 0.25 ve en fazla 0.63 olduğu ve ortalamanın ise 0.38 olduğu görülmektedir.

Tablo 3. UNDP Endeksleri ve Gini katsayısına ilişkin tanımlayıcı istatistikler

\begin{tabular}{|c|c|c|c|c|c|}
\hline Değişken & $\mathbf{N}$ & Min. & Max. & Ort. & SS. \\
\hline İnsani Gelişmişlik Endeksi & 187 & 0.377 & 0.954 & 0.709 & 0.154 \\
\hline $\begin{array}{l}\text { Eşitsizliğe Uyarlanmış İnsani } \\
\text { Gelişmişlik Endeksi }\end{array}$ & 149 & 0.222 & 0.889 & 0.586 & 0.189 \\
\hline Çok Boyutlu Yoksulluk Endeksi & 71 & 0.001 & 0.594 & 0.167 & 0.161 \\
\hline Cinsiyet Eşitsizliği Endeksi & 160 & 0.037 & 0.834 & 0.348 & 0.191 \\
\hline Cinsiyet Gelişmişlik Endeksi & 163 & 0.298 & 1.043 & 0.934 & 0.089 \\
\hline Gini Katsayısı & 151 & 0.250 & 0.630 & 0.380 & 0.076 \\
\hline
\end{tabular}

Tablo 4'te çalışmanın sağlık değişkenlerine ilişkin tanımlayıcı istatistikler verilmektedir. Doğumda beklenen yaşam süresi en az 52.90, en fazla 84.20 iken, doğumda beklenen sağliklı yaşam beklentisi sirasiyla 44.90 ve $76.20^{\prime}$ dir. Her iki beklenen yaşam süresi ortalamasında da kadınlar için beklenen süre erkeklerden fazladır. Neonatal ölüm hızı ortalaması 12.71, beş yaş altı ölüm hızı ortalaması 28.08 ve ana ölüm hızı ortalaması ise 160.81 'dir. Yetişkin ve beş yaş altı bireylerde obezite ve anemi ortalaması $\% 20$ civarındadır. DBT aşısı ve sağlık 
personeli tarafından yaptırılan doğumların ortalaması \%80'den fazladır. Hekim sayısı ortalaması 18.64, ebe-hemşire sayısı ortalaması 44.64, genel sağlık sigortası olanların ortalaması \%64.04 ve kamu harcaması olarak sağlık harcaması oranı ise $\% 10.25$ 'tir.

Tablo 4. Sağlık değişkenlerine ilişkin tanımlayıcı istatistikler

\begin{tabular}{|c|c|c|c|c|c|}
\hline Değişken & & Min. & Max. & Ort. & SS. \\
\hline \multirow[t]{6}{*}{$\begin{array}{l}\text { Yaşam } \\
\text { Beklentisi }\end{array}$} & $\begin{array}{l}\text { Doğumda Beklenen Yaşam } \\
\text { Süresi (Yll) }\end{array}$ & 52.90 & 84.20 & 71.93 & 7.50 \\
\hline & $\begin{array}{l}\text { Erkekler İçin Doğumda } \\
\text { Beklenen Yaşam Süresi (Yıl) }\end{array}$ & 51.00 & 81.20 & 69.58 & 7.24 \\
\hline & $\begin{array}{l}\text { Kadınlar İçin Doğumda } \\
\text { Beklenen Yaşam Süresi (Yıl) }\end{array}$ & 53.80 & 87.10 & 74.32 & 7.89 \\
\hline & $\begin{array}{l}\text { Doğumda Beklenen Sağlıklı } \\
\text { Yaşam Süresi (Yıl) }\end{array}$ & 44.90 & 76.20 & 63.36 & 6.82 \\
\hline & $\begin{array}{llr}\text { Erkekler } & \text { İçin } & \text { Doğumda } \\
\text { Beklenen } & \text { Sağlıklı } & \text { Yaşam } \\
\text { Süresi (Yıl) } & & \end{array}$ & 43.90 & 74.70 & 61.72 & 6.68 \\
\hline & $\begin{array}{llr}\text { Kadınlar } & \text { İçin } & \text { Doğumda } \\
\text { Beklenen } & \text { Sağlıklı } & \text { Yaşam } \\
\text { Süresi (Yll) } & & \end{array}$ & 45.90 & 77.60 & 64.99 & 7.08 \\
\hline \multirow[t]{3}{*}{ Mortalite } & Neo-Natal Ölüm Hızı (\%o) & 1.00 & 42.00 & 12.71 & 10.55 \\
\hline & Beş Yaş Altı Ölüm Hızı (\%o) & 2.00 & 122.00 & 28.08 & 28.36 \\
\hline & Ana Ölüm Oranı ((\%ooo) & 2.00 & 1150 & 160.81 & 233.45 \\
\hline \multirow[t]{4}{*}{ Morbidite } & $\begin{array}{l}18 \text { Yaş Üstü Bireylerde } \\
\text { Obezite }(\%)\end{array}$ & 2.10 & 61.00 & 20.02 & 11.41 \\
\hline & $\begin{array}{l}\text { Beş Yaş Altı Çocuklarda } \\
\text { Obezite }(\%)\end{array}$ & 1.00 & 29.60 & 6.71 & 5.07 \\
\hline & $\begin{array}{l}\text { Beş Yaş Altı Çocuklarda } \\
\text { Bodurluk Prevalansı (\%) }\end{array}$ & 1.70 & 54.20 & 22.02 & 13.37 \\
\hline & $\begin{array}{l}\text { 15-49 Yaş Arası Kadınlarda } \\
\text { Anemi }(\%)\end{array}$ & 9.10 & 69.60 & 29.60 & 11.27 \\
\hline \multirow{4}{*}{$\begin{array}{l}\text { Sağlık } \\
\text { Hizmeti } \\
\text { Kullanımı } \\
\text { ve Sağlık } \\
\text { Altyapısı }\end{array}$} & DBT Aşısı (\%) & 25.00 & 99.00 & 88.14 & 13.76 \\
\hline & $\begin{array}{l}\text { Sağlık Personeli Tarafından } \\
\text { Yaptırılan Doğumlar (\%) }\end{array}$ & 19.00 & 100.00 & 80.20 & 30.45 \\
\hline & Hekim Sayısı (\%oo) & 0.10 & 84.20 & 18.64 & 16.92 \\
\hline & Ebe ve Hemşire Sayısı (\%oo) & 0.10 & 201.60 & 44.48 & 42.96 \\
\hline \multirow[t]{2}{*}{$\begin{array}{l}\text { Sağlık } \\
\text { Sistemi }\end{array}$} & $\begin{array}{l}\text { Genel Sağlık Sigortalısı } \\
\text { (UHS) (\%) }\end{array}$ & 25.00 & 89.00 & 64.04 & 15.59 \\
\hline & 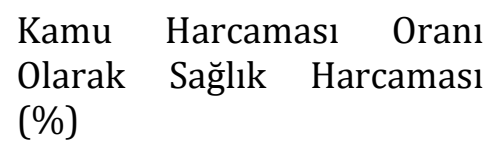 & 1.40 & 26.90 & 10.25 & 5.01 \\
\hline
\end{tabular}


Tablo 5'te İGE ve sağlık göstergeleri arasındaki ilişkiyi gösteren korelasyon analizi sonuçları verilmektedir. Tablo incelendiğinde tüm değişkenlerin istatistiksel olarak anlamlı olduğu görülmektedir. İGE ile 18 yaş üstü bireylerde obezite $(r=0.499)$, beş yaş altı çocuklarda obezite $(r=0.570)$ ve DBT aşısı
( $\mathrm{r}=0.515)$ arasında orta düzeyde; diğer sağlık değişkenleri arasında yüksek ve çok yüksek düzeyde ilişki vardır. İlişkinin yönüne bakıldığında İGE ile ölüm göstergeleri, bodurluk ve anemi göstergeleri arasındaki ilişki negatif, diğer değişkenlerle ilişki ise pozitiftir.

Tablo 5. İnsani Gelişmişlik Endeksi ve sağlık göstergeleri arasındaki ilişki

\begin{tabular}{|c|c|c|c|}
\hline Değişken & & Korelasyon (r) & Anlamlılık (p) \\
\hline \multirow{6}{*}{$\begin{array}{l}\text { Yaşam } \\
\text { Beklentisi }\end{array}$} & Doğumda Beklenen Yaşam Süresi & 0.916 & $<0.001$ \\
\hline & $\begin{array}{l}\text { Erkekler İçin Doğumda Beklenen Yaşam } \\
\text { Süresi }\end{array}$ & 0.889 & $<0.001$ \\
\hline & $\begin{array}{l}\text { Kadınlar İçin Doğumda Beklenen Yaşam } \\
\text { Süresi }\end{array}$ & 0.928 & $<0.001$ \\
\hline & $\begin{array}{l}\text { Doğumda Beklenen Sağlıklı Yaşam } \\
\text { Süresi }\end{array}$ & 0.915 & $<0.001$ \\
\hline & $\begin{array}{l}\text { Erkekler İçin Doğumda Beklenen Sağlıklı } \\
\text { Yaşam Süresi }\end{array}$ & 0.893 & $<0.001$ \\
\hline & $\begin{array}{l}\text { Kadınlar İçin Doğumda Beklenen Sağlıklı } \\
\text { Yaşam Süresi }\end{array}$ & 0.920 & $<0.001$ \\
\hline \multirow[t]{3}{*}{ Mortalite } & Neo-Natal Ölüm Hızı & -0.905 & $<0.001$ \\
\hline & Beş Yaş Altı Ölüm Hızı & -0.925 & $<0.001$ \\
\hline & Ana Ölüm Oranı & -0.920 & $<0.001$ \\
\hline \multirow[t]{4}{*}{ Morbidite } & 18 Yaş Üstü Bireylerde Obezite & 0.499 & $<0.001$ \\
\hline & Beş Yaş Altı Çocuklarda Obezite & 0.570 & $<0.001$ \\
\hline & $\begin{array}{l}\text { Beş Yaş Altı Çocuklarda Bodurluk } \\
\text { Prevalansı }\end{array}$ & -0.804 & $<0.001$ \\
\hline & 15-49 Yaş Arası Kadınlarda Anemi & -0.718 & $<0.001$ \\
\hline \multirow{4}{*}{$\begin{array}{l}\text { Sağlık } \\
\text { Hizmeti } \\
\text { Kullanımı ve } \\
\text { Sağlık } \\
\text { Altyapısı }\end{array}$} & DBT Așısı & 0.515 & $<0.001$ \\
\hline & $\begin{array}{l}\text { Sağllk Personeli Tarafından Yaptırılan } \\
\text { Doğumlar }\end{array}$ & 0.920 & $<0.001$ \\
\hline & Hekim Sayısı & 0.868 & $<0.001$ \\
\hline & Ebe ve Hemşire Sayısı & 0.772 & $<0.001$ \\
\hline \multirow{2}{*}{$\begin{array}{l}\text { Sağllk } \\
\text { Sistemi }\end{array}$} & Genel Sağlık Sigortalısı (UHS) & 0.901 & $<0.001$ \\
\hline & $\begin{array}{l}\text { Kamu Harcaması Oranı Olarak Sağlık } \\
\text { Harcaması }\end{array}$ & 0.667 & $<0.001$ \\
\hline
\end{tabular}


Tablo 6'da EUİGE ve sağllk göstergeleri arasındaki ilişkiyi gösteren korelasyon analizi sonuçları verilmektedir. Tablo incelendiğinde tüm değişkenlerin istatistiksel olarak anlamlı olduğu görülmektedir. EUİGE ile 18 yaş üstü bireylerde obezite $(\mathrm{r}=0.518)$, beş yaş altı çocuklarda obezite $(\mathrm{r}=0.549)$ ve DBT aşısı
( $\mathrm{r}=0.524)$ orta düzeyde, diğer sağlık değişkenleri ise yüksek ve çok yüksek düzeyde istatistiksel olarak anlamlı şekilde ilişkilidir. İlişkinin yönüne bakıldığında EUİGE ile ölüm göstergeleri, bodurluk ve anemi göstergeleri arasındaki ilişki negatif, diğer değişkenlerle ilişki ise pozitiftir.

Tablo 6. Eşitsizliğe Uyarlanmış İnsani Gelişmişlik Endeksi ve sağlık göstergeleri arasındaki ilişki

\begin{tabular}{|c|c|c|c|}
\hline Değişken & & Korelasyon (r) & Anlamlılık (p) \\
\hline \multirow{6}{*}{$\begin{array}{l}\text { Yaşam } \\
\text { Beklentisi }\end{array}$} & Doğumda Beklenen Yaşam Süresi & 0.882 & $<0.001$ \\
\hline & $\begin{array}{l}\text { Erkekler İçin Doğumda Beklenen Yaşam } \\
\text { Süresi }\end{array}$ & 0.859 & $<0.001$ \\
\hline & $\begin{array}{l}\text { Kadınlar İçin Doğumda Beklenen Yaşam } \\
\text { Süresi }\end{array}$ & 0.896 & $<0.001$ \\
\hline & $\begin{array}{l}\text { Doğumda Beklenen Sağlıklı Yaşam } \\
\text { Süresi }\end{array}$ & 0.879 & $<0.001$ \\
\hline & $\begin{array}{l}\text { Erkekler İçin Doğumda Beklenen Sağlıklı } \\
\text { Yaşam Süresi }\end{array}$ & 0.859 & $<0.001$ \\
\hline & $\begin{array}{l}\text { Kadınlar İçin Doğumda Beklenen Sağlıklı } \\
\text { Yaşam Süresi }\end{array}$ & 0.891 & $<0.001$ \\
\hline \multirow[t]{3}{*}{ Mortalite } & Neo-Natal Ölüm Hızı & -0.905 & $<0.001$ \\
\hline & Beș Yaş Altı Ölüm Hızı & -0.916 & $<0.001$ \\
\hline & Ana Ölüm Oranı & -0.904 & $<0.001$ \\
\hline \multirow[t]{4}{*}{ Morbidite } & 18 Yaş Üstü Bireylerde Obezite & 0.518 & $<0.001$ \\
\hline & Beş Yaş Altı Çocuklarda Obezite & 0.549 & $<0.001$ \\
\hline & $\begin{array}{l}\text { Beş Yaş Altı Çocuklarda Bodurluk } \\
\text { Prevalansı }\end{array}$ & -0.805 & $<0.001$ \\
\hline & 15-49 Yaş Arası Kadınlarda Anemi & -0.682 & $<0.001$ \\
\hline \multirow{4}{*}{$\begin{array}{l}\text { Sağlık } \\
\text { Hizmeti } \\
\text { Kullanımı ve } \\
\text { Sağlık } \\
\text { Altyapısı }\end{array}$} & DBT Așısı & 0.524 & $<0.001$ \\
\hline & $\begin{array}{l}\text { Sağllk Personeli Tarafından Yaptırılan } \\
\text { Doğumlar }\end{array}$ & 0.904 & $<0.001$ \\
\hline & Hekim Sayısı & 0.849 & $<0.001$ \\
\hline & Ebe ve Hemşire Sayısı & 0.769 & $<0.001$ \\
\hline \multirow{2}{*}{$\begin{array}{l}\text { Sağllk } \\
\text { Sistemi }\end{array}$} & Genel Sağlık Sigortalısı (UHS) & 0.856 & $<0.001$ \\
\hline & $\begin{array}{l}\text { Kamu Harcaması Oranı Olarak Sağlık } \\
\text { Harcaması }\end{array}$ & 0.610 & $<0.001$ \\
\hline
\end{tabular}


ÇBYE ile beş grupta yer alan sağlık değişkenleri arasında istatistiksel açıdan anlamlı ilişkiler bulunmaktadır. ÇBYE ile ölüm oranı gibi olumsuz değişkenler pozitif, doğumda beklenen yaşam süresi gibi olumlu değişkenler arasında ise negatif ilişki vardır. ÇBYE ile 18 yaş üstü bireylerde obezite $(r=-0.638)$, beş yaş altı bireylerde obezite ( $\mathrm{r}=$-0.689), 15-49 yaş arası kadınlarda anemi ( $\mathrm{r}=0.507)$, DBT aşısı ( $\mathrm{r}=$ 0.481) ve kamu harcaması oranı olarak sağlık harcaması ( $\mathrm{r}=-0.469)$ arasında orta düzeyde, diğer sağlık değişkenleri arasında yüksek ve çok yüksek düzeyde ilişkilidir (bkz. Tablo 7).

Tablo 7. Çok Boyutlu Yoksulluk Endeksi ve sağlık göstergeleri arasındaki ilişki

\begin{tabular}{|c|c|c|c|}
\hline Değişken & & Korelasyon (r) & Anlamlılık (p) \\
\hline \multirow{6}{*}{$\begin{array}{l}\text { Yaşam } \\
\text { Beklentisi }\end{array}$} & Doğumda Beklenen Yaşam Süresi & -0.808 & $<0.001$ \\
\hline & $\begin{array}{l}\text { Erkekler İçin Doğumda Beklenen } \\
\text { Yaşam Süresi }\end{array}$ & -0.774 & $<0.001$ \\
\hline & $\begin{array}{l}\text { Kadınlar İçin Doğumda Beklenen } \\
\text { Yaşam Süresi }\end{array}$ & -0.883 & $<0.001$ \\
\hline & $\begin{array}{l}\text { Doğumda Beklenen Sağlıklı Yaşam } \\
\text { Süresi }\end{array}$ & -0.828 & $<0.001$ \\
\hline & $\begin{array}{l}\text { Erkekler İçin Doğumda Beklenen } \\
\text { Sağlıklı Yaşam Süresi }\end{array}$ & -0.797 & $<0.001$ \\
\hline & $\begin{array}{l}\text { Kadınlar İçin Doğumda Beklenen } \\
\text { Sağlıklı Yaşam Süresi }\end{array}$ & -0.837 & $<0.001$ \\
\hline \multirow[t]{3}{*}{ Mortalite } & Neo-Natal Ölüm Hızı & 0.827 & $<0.001$ \\
\hline & Beş Yaş Altı Ölüm Hızı & 0.864 & $<0.001$ \\
\hline & Ana Ölüm Oranı & 0.835 & $<0.001$ \\
\hline \multirow[t]{4}{*}{ Morbidite } & 18 Yaş Üstü Bireylerde Obezite & -0.638 & $<0.001$ \\
\hline & Beş Yaş Altı Çocuklarda Obezite & -0.689 & $<0.001$ \\
\hline & $\begin{array}{l}\text { Beş Yaş Altı Çocuklarda Bodurluk } \\
\text { Prevalansı }\end{array}$ & 0.768 & $<0.001$ \\
\hline & 15-49 Yaş Arası Kadınlarda Anemi & 0.507 & $<0.001$ \\
\hline \multirow{4}{*}{$\begin{array}{l}\text { Sağlık } \\
\text { Hizmeti } \\
\text { Kullanımı } \\
\text { ve Sağlık } \\
\text { Altyapısı }\end{array}$} & DBT Aşısı & -0.481 & $<0.001$ \\
\hline & $\begin{array}{l}\text { Sağlık Personeli } \\
\text { Yaptırılan Doğumlar }\end{array}$ & -0.835 & $<0.001$ \\
\hline & Hekim Sayısı & -0.807 & $<0.001$ \\
\hline & Ebe ve Hemşire Sayısı & -0.783 & $<0.001$ \\
\hline \multirow{2}{*}{$\begin{array}{l}\text { Sağlık } \\
\text { Sistemi }\end{array}$} & Genel Sağlık Sigortalısı (UHS) & -0.860 & $<0.001$ \\
\hline & $\begin{array}{l}\text { Kamu Harcaması Oranı Olarak Sağlık } \\
\text { Harcaması }\end{array}$ & -0.469 & $<0.001$ \\
\hline
\end{tabular}


Tablo 8'de CEE ile sağlık değișkenleri arasındaki ilişki verilmektedir. Endeks ile sağlık göstergeleri arasındaki ilişki çok boyutlu yoksulluk endeksi ile sağlı değişkenleri arasındaki ilişkiye benzerdir. CEE ile 18 yaş üstü bireylerde obezite $(r=-$ $0.413)$, beş yaş altı bireylerde obezite ( $r=-$
0.540), 15-49 yaş arası kadınlarda anemi $(\mathrm{r}=0.687)$, DBT aşısı ( $\mathrm{r}=-0.503)$ ve kamu harcaması oranı olarak sağlı harcaması ( $r=-0.566)$ arasında orta düzeyde, diğer sağlık değişkenleri arasında yüksek ve çok yüksek düzeyde ilişkilidir.

Tablo 8. Cinsiyet Eşitsizliği Endeksi ve sağllk göstergeleri arasındaki ilişki

\begin{tabular}{|c|c|c|c|}
\hline Değişken & & Korelasyon (r) & Anlamlılık (p) \\
\hline \multirow{6}{*}{$\begin{array}{l}\text { Yaşam } \\
\text { Beklentisi }\end{array}$} & Doğumda Beklenen Yaşam Süresi & -0.877 & $<0.001$ \\
\hline & $\begin{array}{l}\text { Erkekler İçin Doğumda Beklenen } \\
\text { Yaşam Süresi }\end{array}$ & -0.845 & $<0.001$ \\
\hline & $\begin{array}{l}\text { Kadınlar İçin Doğumda Beklenen } \\
\text { Yaşam Süresi }\end{array}$ & -0.893 & $<0.001$ \\
\hline & $\begin{array}{l}\text { Doğumda Beklenen Sağlıklı Yaşam } \\
\text { Süresi }\end{array}$ & -0.880 & $<0.001$ \\
\hline & $\begin{array}{l}\text { Erkekler İçin Doğumda Beklenen } \\
\text { Sağlıklı Yaşam Süresi }\end{array}$ & -0.850 & $<0.001$ \\
\hline & $\begin{array}{l}\text { Kadınlar İçin Doğumda Beklenen } \\
\text { Sağlıklı Yaşam Süresi }\end{array}$ & -0.887 & $<0.001$ \\
\hline \multirow[t]{3}{*}{ Mortalite } & Neo-Natal Ölüm Hızı & 0.926 & $<0.001$ \\
\hline & Beş Yaş Altı Ölüm Hızı & 0.940 & $<0.001$ \\
\hline & Ana Ölüm Oranı & 0.933 & $<0.001$ \\
\hline \multirow[t]{4}{*}{ Morbidite } & 18 Yaş Üstü Bireylerde Obezite & -0.413 & $<0.001$ \\
\hline & Beş Yaş Altı Çocuklarda Obezite & -0.540 & $<0.001$ \\
\hline & $\begin{array}{l}\text { Beş Yaş Altı Çocuklarda Bodurluk } \\
\text { Prevalansı }\end{array}$ & 0.712 & $<0.001$ \\
\hline & 15-49 Yaş Arası Kadınlarda Anemi & 0.687 & $<0.001$ \\
\hline \multirow{4}{*}{$\begin{array}{l}\text { Sağlık } \\
\text { Hizmeti } \\
\text { Kullanımı } \\
\text { ve Sağlık } \\
\text { Altyapısı }\end{array}$} & DBT Aşısı & -0.503 & $<0.001$ \\
\hline & $\begin{array}{l}\text { Sağlık Personeli } \\
\text { Yaptırılan Doğumlar }\end{array}$ & -0.933 & $<0.001$ \\
\hline & Hekim Sayısı & -0.847 & $<0.001$ \\
\hline & Ebe ve Hemşire Sayısı & -0.797 & $<0.001$ \\
\hline \multirow{2}{*}{$\begin{array}{l}\text { Sağlık } \\
\text { Sistemi }\end{array}$} & Genel Sağlık Sigortalısı (UHS) & -0.832 & $<0.001$ \\
\hline & $\begin{array}{l}\text { Kamu Harcaması Oranı Olarak Sağlık } \\
\text { Harcaması }\end{array}$ & -0.566 & $<0.001$ \\
\hline
\end{tabular}


Tablo 9'da CGE ile çeşitli sağlık göstergeleri arasındaki ilişki verilmektedir. Endeks ile sağllk değişkenleri arasında orta ve zayıf düzeyde istatistiksel olarak anlamlı ilișkiler bulunmaktadır. CGE ile neo-natal ölüm hızı, beş yaş altı ölüm hızı, ana ölüm oranı, beş yaş altı çocuklarda bodurluk prevalansı ve 15-49 yaș arası kadınlarda anemi arasında ters yönlü (negatif) ilişki bulunmaktadır.

Tablo 9. Cinsiyet Gelişmişlik Endeksi ve sağlık göstergeleri arasındaki ilişki

\begin{tabular}{|c|c|c|c|}
\hline Değişken & & Korelasyon (r) & Anlamlılık (p) \\
\hline \multirow{6}{*}{$\begin{array}{l}\text { Yaşam } \\
\text { Beklentisi }\end{array}$} & Doğumda Beklenen Yaşam Süresi & 0.479 & $<0.001$ \\
\hline & $\begin{array}{l}\text { Erkekler İçin Doğumda Beklenen } \\
\text { Yaşam Süresi }\end{array}$ & 0.406 & $<0.001$ \\
\hline & $\begin{array}{l}\text { Kadınlar İçin Doğumda Beklenen } \\
\text { Yaşam Süresi }\end{array}$ & 0.555 & $<0.001$ \\
\hline & $\begin{array}{l}\text { Doğumda Beklenen Sağlıklı Yaşam } \\
\text { Süresi }\end{array}$ & 0.527 & $<0.001$ \\
\hline & $\begin{array}{l}\text { Erkekler İçin Doğumda Beklenen } \\
\text { Sağllklı Yaşam Süresi }\end{array}$ & 0.443 & $<0.001$ \\
\hline & $\begin{array}{l}\text { Kadınlar İçin Doğumda Beklenen } \\
\text { Sağlıklı Yaşam Süresi }\end{array}$ & 0.587 & $<0.001$ \\
\hline \multirow[t]{3}{*}{ Mortalite } & Neo-Natal Ölüm Hızı & -0.584 & $<0.001$ \\
\hline & Beş Yaş Altı Ölüm Hızı & -0.582 & $<0.001$ \\
\hline & Ana Ölüm Oranı & -0.535 & $<0.001$ \\
\hline \multirow[t]{4}{*}{ Morbidite } & 18 Yaş Üstü Bireylerde Obezite & 0.346 & $<0.001$ \\
\hline & Beş Yaş Altı Çocuklarda Obezite & 0.391 & $<0.001$ \\
\hline & $\begin{array}{l}\text { Beş Yaş Altı Çocuklarda Bodurluk } \\
\text { Prevalansı }\end{array}$ & -0.492 & $<0.001$ \\
\hline & 15-49 Yaş Arası Kadınlarda Anemi & -0.648 & $<0.001$ \\
\hline \multirow{4}{*}{$\begin{array}{l}\text { Sağlık } \\
\text { Hizmeti } \\
\text { Kullanımı } \\
\text { ve Sağlık } \\
\text { Altyapısı }\end{array}$} & DBT Aşısı & 0.332 & $<0.001$ \\
\hline & $\begin{array}{l}\text { Sağlık Personeli } \\
\text { Yaptırılan Doğumlar }\end{array}$ & 0.535 & $<0.001$ \\
\hline & Hekim Sayısı & 0.576 & $<0.001$ \\
\hline & Ebe ve Hemşire Sayısı & 0.533 & $<0.001$ \\
\hline \multirow{2}{*}{$\begin{array}{l}\text { Sağlık } \\
\text { Sistemi }\end{array}$} & Genel Sağlık Sigortalısı (UHS) & 0.581 & $<0.001$ \\
\hline & $\begin{array}{l}\text { Kamu Harcaması Oranı Olarak Sağlık } \\
\text { Harcaması }\end{array}$ & 0.481 & $<0.001$ \\
\hline
\end{tabular}


Tablo 10'da Gini katsayısı ve sağlık değişkenleri arasındaki ilişki verilmektedir. Tablo incelendiğinde Gini katsayısı ile sağlık değişkenleri arasındaki orta ve zayıf düzeyde ilişki olduğu; beş yaş altı çocuklarda obezite ve 15-49 yaş arası kadınlarda anemi değişkeni arasında ise istatistiksel olarak anlamlı ilişki olmadığı görülmektedir. Gini katsayısı ile yaşam beklentisi, sağlık hizmeti kullanımı ve sağlık altyapısı ve sağlık sistemi göstergeleri arasında negatif, mortalite ve morbidite göstergeleri arasında pozitif ilişki bulunmaktadır.

Tablo 10. Gini katsayısı ve sağlık göstergeleri arasındaki ilişki

\begin{tabular}{|c|c|c|c|}
\hline Değişken & & Korelasyon (r) & Anlamlılık (p) \\
\hline \multirow{6}{*}{$\begin{array}{l}\text { Yaşam } \\
\text { Beklentisi }\end{array}$} & Doğumda Beklenen Yaşam Süresi & -0.442 & $<0.001$ \\
\hline & $\begin{array}{l}\text { Erkekler İçin Doğumda Beklenen } \\
\text { Yaşam Süresi }\end{array}$ & -0.437 & $<0.001$ \\
\hline & $\begin{array}{l}\text { Kadınlar İçin Doğumda Beklenen } \\
\text { Yaşam Süresi }\end{array}$ & -0.443 & $<0.001$ \\
\hline & $\begin{array}{l}\text { Doğumda Beklenen Sağlıklı Yaşam } \\
\text { Süresi }\end{array}$ & -0.425 & $<0.001$ \\
\hline & $\begin{array}{l}\text { Erkekler İçin Doğumda Beklenen } \\
\text { Sağlıklı Yaşam Süresi }\end{array}$ & -0.421 & $<0.001$ \\
\hline & $\begin{array}{l}\text { Kadınlar İçin Doğumda Beklenen } \\
\text { Sağlıklı Yaşam Süresi }\end{array}$ & -0.430 & $<0.001$ \\
\hline \multirow[t]{3}{*}{ Mortalite } & Neo-Natal Ölüm Hızı & 0.500 & $<0.001$ \\
\hline & Beş Yaş Altı Ölüm Hızı & 0.514 & $<0.001$ \\
\hline & Ana Ölüm Oranı & 0.563 & $<0.001$ \\
\hline \multirow[t]{4}{*}{ Morbidite } & 18 Yaş Üstü Bireylerde Obezite & -0.166 & 0.043 \\
\hline & Beş Yaş Altı Çocuklarda Obezite & 0.009 & 0.925 \\
\hline & $\begin{array}{l}\text { Beş Yaş Altı Çocuklarda Bodurluk } \\
\text { Prevalansı }\end{array}$ & 0.236 & 0.015 \\
\hline & 15-49 Yaş Arası Kadınlarda Anemi & 0.154 & 0.060 \\
\hline \multirow{4}{*}{$\begin{array}{l}\text { Sağlık } \\
\text { Hizmeti } \\
\text { Kullanımı } \\
\text { ve Sağlık } \\
\text { Altyapısı }\end{array}$} & DBT Aşısı & -0.293 & $<0.001$ \\
\hline & $\begin{array}{l}\text { Sağlık Personeli } \\
\text { Yaptırllan Doğumlar }\end{array}$ & -0.563 & $<0.001$ \\
\hline & Hekim Sayısı & -0.477 & $<0.001$ \\
\hline & Ebe ve Hemşire Sayısı & -0.446 & $<0.001$ \\
\hline \multirow{2}{*}{$\begin{array}{l}\text { Sağlık } \\
\text { Sistemi }\end{array}$} & Genel Sağlık Sigortalısı (UHS) & -0.370 & $<0.001$ \\
\hline & $\begin{array}{l}\text { Kamu Harcaması Oranı Olarak Sağlık } \\
\text { Harcaması }\end{array}$ & -0.185 & 0.024 \\
\hline
\end{tabular}




\section{Tartışma ve Sonuç}

$\mathrm{Bu}$ çalışma, UNDP Endeksleri ve Gini katsayısı ile sağlık değișkenleri arasındaki ilişkinin belirlenmesi amaciyla gerçekleştirilmiştir. Çalışma, 194 DSÖ üyesi ülkeyi kapsamaktadır. Çalışmanın amacı doğrultusunda ülkelerin endeks değerleri ve sağlı değişkenleri ilgili veri tabanlarından ulaşılarak analiz edilmiştir.

Yapılan analizler doğrultusunda İGE ve EUİGE ile sağlık değişkenlerinin tamamı arasında istatistiksel olarak anlamlı ilişkiler bulunmuştur. İGE ve EUIGGE ile yaşam süreleri, obezite, aşı, hekim, hemşire-ebe sayısı, GSS ve sağlık harcaması arasında pozitif ilișki bulunmuştur. $\mathrm{Bu}$ durum gelişmişlik arttıkça bu değişkenlerin arttığı ya da gelişmişlik azaldıkça bu değişkenlerin azaldığ şeklinde yorumlanabilir. İGE ve EUIGGE arasında ölüm hızları, bodurluk ve anemi arasında negatif ilişki olduğu saptanmıştır. $\mathrm{Bu}$ bulgu gelişmişlikle bu değişkenlerin ters yönlü ilişki içinde olduğunu diğer bir ifadeyle gelişmişlik arttıkça bu değişkenlerin azaldığını gösterdiği söylenebilir. Bu bulgular Aba ve Ateş (2015) ${ }^{13}$ tarafından yapılan çalışma bulguları ile uyumludur. $\mathrm{Bu}$ bulgular, gelişmişliği iyileştirmenin diğer faydaları yanında sağlığı da artıracağı, sağlık arttıkça gelişmişliğin daha da artacağı şeklinde yorumlanabilir.

Çalışmada yoksulluk ölçütlerinden çok boyutlu yoksulluk endeksi ile sağlık değişkenleri arasındaki ilişki incelenmiş ve yoksulluk arttıkça sağlık değişkenlerinin olumsuzlaştığı belirlenmiştir. Yoksulluk çok boyutlu bir olgu olması nedeniyle çeșitli disiplinlerin çalışma alanıdır ve alanyazında yoksulluk-sağlık arasındaki ilişki ya da yoksulluğun sağlık üzerindeki etkisini araştıran çalışmalar bulunmaktadır. Çalışmalarda yoksulluğun sağlıksızlığa neden olduğu saptanmıştır. ${ }^{14,15,16}$ Yoksulluğun ortadan kaldırılması bașta Binyıl Kalkınma Hedefleri olmak üzere çeşitli platformlarda dile getirilen bir husustur. Yoksulluk azaltıldıkça sağlık ile ilgili değiş̧kenler de olumlu hale gelecektir.

Çalışmanın bir diğer bulgusu, cinsiyet eşitsizliği arttıkça ya da cinsiyet gelişmişliği azaldıkça sağlı göstergelerinin olumsuzlaşmasıdır. Yapılan analizlere bakıldığında cinsiyet eşitsizliği endeksi ve cinsiyet gelişme endeksi ile sağlık değişkenlerinin tamamı arasında istatistiksel olarak anlaml korelasyon bulunmaktadır. Alanyazın incelendiğinde cinsiyet eşitsizliğinin sağlık statüsü, sağlık hizmetleri kullanımı ve sağlık riskleri açısından olumsuzluk oluşturduğunu gösteren çalışmalar bulunmaktadır. ${ }^{17,18,19}$ Cinsiyet eşitsizliğini azaltmak diğer bir ifadeyle kadınları güçlendirerek erkekkadın arasındaki cinsiyetten kaynaklı farklılıkları azaltmak daha iyi sağlık anlamına da gelecektir.

Çalışmada gelir dağılımı-sağlık ilişkisi de incelenmiștir. Gini katsayısı ile yaşam beklentisi, sağlık hizmeti kullanımı ve sağlık altyapısı ve sağlık sistemi göstergeleri arasinda negatif, mortalite ve morbidite göstergeleri arasında pozitif ilişki bulunmaktadır. Çalışmanın bulguları Çukur ve Bekmez (2011) ${ }^{20}$ tarafindan yapılan çalışma ile uyumludur. Çalışmanın bu bulgusu doğrultusunda gelir dağılımında eşitsizliğin azaltılmasının aynı zamanda sağlığa bir yatırım olacağı söylenebilir.

$\mathrm{Bu}$ çalışma sonunda insani gelişmişliği artırmanın, cinsiyet eşitsizliğini, yoksulluğu ve gelir dağılımında eşitsizliği azaltmanın sağlık için pozitif etki yapacağı söylenebilir. $\mathrm{Bu}$ çalışmanın son derece sınırlı çalışma olan ilgili alanyazına katkı sağlayacağı düşünülmekle birlikte çalışmanın sinırlılıkları ve bu doğrultuda ileride yapılacak çalışmalara yönelik öneriler bulunmaktadır. Çalışmada yaşam beklentisi hem sağlık değişkeni olarak ele alınmış hem de UNDP'nin geliștirdiği endekslerde bir bileşen olarak kullanılmıştır. $\mathrm{Bu}$ durum çalışmanın sınırlılığı olarak ifade edilebilir. Araştırmada ikincil verilerin kullanılması sebebiyle çalışma ulaşılabilen veriler doğrultusunda tasarlanıp, gerçekleştirilmiştir. $\mathrm{Bu}$ durumun da çalışmanın sinırlılığı olduğu söylenebilir. Sinırlılık olarak ifade edilecek bir diğer husus, çalışma Dünya Sağlık Örgütü üyesi 194 ülkeyi kapsamasına rağmen ülkelerin tamaminda UNDP Endeksleri ve Gini katsayısı verileri olmadığı için çalışma, verileri tam olan ülkeler üzerinden gerçekleştirilmiştir. 
Bu çalışma 194 DSÖ üyesini kapsamaktadır ve analizde en güncel veriler kullanılmıștır. Analizlerde korelasyon analizi kullanılmıştır. İleride daha uzun dönemli veriler kullanılarak panel veri analizi yapılabilir. $\mathrm{Bu}$ şekilde bu çalışmada ilişki bulunan değişkenler arasında neden-sonuç etkisi test edilebilir.

\section{Destek}

Herhangi bir destek alınmamıştır.

\section{Çıkar Çatışması}

Çıkar çatışması bulunmamaktadır.

\section{Kaynaklar}

1. Karaca AA, Şahin B. Kalkınma modellerine teorik yaklaşımlar. ABMYO Dergisi 2010; 18: 41-52.

2. Arslan GE. Ekonomik büyüme, kalkınma ve gelir dağılımı. Hitit Üniversitesi Sosyal Bilimler Enstitüsü Dergisi 2013; 6(2): 45-52.

3. Çelik Y. Sağlık Ekonomisi. Ankara: 4. Baskı, Siyasal Kitabevi, 2019.

4. UNDP. Human Development Index (HDI), Available at: http://hdr.undp.org/en/content/huma n-development-index-hdi, Accessed August 28, 2020.

5. UNDP. Human Development Report 2019, Beyond income, beyond averages, beyond today: Inequalities in human development in the 21st century, Available at: http://hdr.undp.org/sites/default/files /hdr2019.pdf, Accessed August 27, 2020.

6. UNDP. Human Development Report 2019 Technical Notes, Available at:mhttp://hdr.undp.org/sites/default /files/hdr2019_technical_notes.pdf, Accessed August 27, 2020.

7. Hagenaars A. de Vos K. The definition and measurement of poverty. The Journal of Human Resources 1988; 23(2): 211-221.

8. Bildirici Z. Avrupa Birliği'nde yoksullukla mücadele ve Türkiye'nin uyum sürecindeki yeni uygulamalar. İstanbul: İstanbul Üniversitesi Sosyal
Bilimler Enstitüsü Avrupa Birliği ABD, Yüksek Lisans Tezi, 2011.

9. Arpacioğlu Ö. Dünyada ve Türkiye'de yoksulluk ve yoksullukla mücadele. Gaziantep: Gaziantep Üniversitesi Sosyal Bilimler Enstitüsü İktisat Anabilim Dalı, Yüksek Lisans Tezi, 2012.

10. Devlet Planlama Teşkilatı. Gelir dağılımının iyileștirilmesi ve yoksullukla mücadele özel ihtisas komisyonu raporu, Ankara, 2001.

11. Özdal H. Gelir dağılımı ve yoksulluk ilişkisi ve Türkiye örneği. Konya: Selçuk Üniversitesi Sosyal Bilimler Enstitüsü İktisat Anabilim Dalı, Yüksek Lisans Tezi, 2009.

12. WHO (2020). Global Health Observatory (GHO) Data. https://www.who.int/gho/publication s/world_health_statistics/2020/en/ Erişim: 17.07.2020.

13. Aba G, Ateş M. (2015). Sağlıkta Eşitsizlikler. İstanbul: 1. Baskl, Beta Yayınevi, 2015.

14. Siziya S, Muula AS, Rudatsikira E. Correlates of diarrhea among children below the age of 5 years in Sudan. African Health Sciences 2013; 13(2): 376-383.

15. Tadesse S, Alemu Y. Urban-rural differentials in child undernutrition in Ethiopia. International Journal of Nutrition and Metabolism, 2014; 7(1): 15-23.

16. Şantaş F. Beş yaş altı ölümü üzerinde yoksulluk ve sağlıkta dönüşüm programinın etkisi. Sosyal Politika Çalışmaları Dergisi 2019; 19(45): 919934.

17. Akın A. Toplumsal cinsiyet (gender) ayırımcılığı ve sağlık. Toplum Hekimliği Bülteni 2007; 26(2): 1-9.

18. Gönç Şavran T, Sağllkta toplumsal cinsiyet eşitsizlikleri: Eskişehir'de kırsal ve kentsel alanlarda kadın sağlığı. Fe Dergi 2014; 6(1): 98-116.

19. Orhan B, Reşat Yücel Ö. Türkiye'de sağlık hizmetleri sunumuna cinsiyet açısından bakış. Marmara Üniversitesi Kadın ve Toplumsal Cinsiyet Araştırmaları Dergisi 2017; 1: 53-59.

20. Çukur A, Bekmez S. Türkiye'de gelir, gelir eşitsizliği ve sağlık ilişkisi: Panel 
veri analizi bulguları Gaziantep Üniversitesi Sosyal Bilimler Dergisi 2011; 10(1): $21-40$. 